\title{
El testimonio y la experiencia de la muerte. Raúl González Tuñón
}

\author{
Eugenia Straccali ${ }^{1}$
}

Resumen. La mirada del que testimonia no sólo es prueba, evidencia, también se impone como lugar simbólico desde el cual se narra una experiencia única e irrepetible. Raúl González Tuñón configura un sujeto ficcional y testimonial, pero no se inscribe como autoridad que presenta la verdad de lo acontecido, sino como sujeto garante de una experiencia inenarrable, la de la muerte. Ese sujeto ficcional, poético, habla de la muerte y recupera esta experiencia de lo real como vivencia, rescata lo impresentable, estetiza, da a conocer zonas veladas de lo real. El tipo de sujeto que rubrica un testimonio no se verá implicado solo como testigo que ve y da fe de lo visto, sino que se construye desde una posición de sujeto partícipe que postula una versión posible de lo ocurrido y además cuestiona otras versiones: todo lo testimoniado depende de una enunciación que es siempre postura y selección.

Palabras clave: Raúl González Tuñón; sujeto testimonial; muerte; experiencia; memoria.

\section{[en] The testimony and experience of death. Raúl González Tuñón}

\begin{abstract}
The gaze that witness is not only proof, evidence, it is also the symbolic place from which an unique and unrepeatable experience is narrated. Raúl González Tuñón shapes a fictional and testimonial subject, but he does not inscribe himself as an authority that presents the truth of the occurred, but as a subject guarantor of an indescribable experience, that of the death. This fictional, poetic subject talks about the death and recovers this experience of the real as what is lived, rescues the unpresentable, aestheticizes, enlightens veiled zones of the real. The type of subjects that stands for a testimony is not only implied as witness that sees and attests what he saw, but is constructed from a position of participant subject that proposes a possible version of what happened and also questions other versions: everything witnessed depends of an enunciation that is always position and selection.
\end{abstract}

Keywords: Raúl González Tunón; testimonial subject; death; experience; memory.

Sumario. 1. Las imágenes de la muerte. 2. La rosa blindada y La muerte en Madrid: testimonios presenciales. 3. Himno de pólvora. Tiempo del héroe. Poesía de guerra (1943). 4. Demanda contra el olvido: la ausencia presente. 5. Conclusión.

Cómo citar: Straccali, E. (2017) El testimonio y la experiencia de la muerte. Raúl González Tuñón, en Anales de Literatura Hispanoamericana 46, 375-390.

1 Universidad Nacional de La Plata (UNLP), Argentina.

E-mail: eustraccali@yahoo.com.ar 
"Tu alto Réquiem vendrá al césped de mi sueño"

John Keats

\section{Las imágenes de la muerte}

La mirada del que testimonia no sólo es prueba, evidencia, también se impone como lugar simbólico desde el cual se narra una experiencia única e irrepetible. Raúl González Tuñón configura un sujeto ficcional y testimonial, pero no se inscribe como autoridad que presenta la verdad de lo acontecido, sino como sujeto garante de una experiencia inenarrable, la de la muerte. Se analizará este sujeto testimonial, ficcional y poético, que habla de la muerte, a partir de un corpus que abarca distintos contextos históricos: a) La rosa blindada (1935) y La Muerte en Madrid (1936), libros escritos en el contexto de la masacre de los mineros en Asturias y de la Guerra Civil en España, momento en el que Tuñón fue testigo directo de los hechos; b) Himno de pólvora (1943), en el que el autor, lejos del lugar de los acontecimientos (se encuentra en Chile), encuentra a través de la poesía la posibilidad de testimoniar tanto los horrores del nazismo como la promesa del proyecto soviético; y c) Demanda contra el olvido (1968), antología de epitafios en la que, retomando las modalidades poéticas de Edgar Lee Masters, el poeta cede su voz a los muertos, tanto anónimos como de la tradición literaria. El tipo de sujeto que rubrica un testimonio no se verá implicado solo como testigo que ve y da fe de lo visto, sino que se construye desde una posición de sujeto partícipe que postula una versión posible de lo ocurrido y además cuestiona otras versiones: todo lo testimoniado depende de una enunciación que es siempre postura y selección. El principal problema del testimonio como género ha sido la peculiar relación que establece entre lo real y la ficción, entre lo "testimonial" y su construcción narrativa, es decir, cómo la literatura trama hechos efectivamente ocurridos, verificables. En general, la crítica lo ha estudiado como una especie de "híbrido" que contacta la literatura con la "realidad" o la verdad de los hechos. Entre las múltiples oposiciones que lo definen (ficción/realidad, objetividad/subjetividad, periodismo/literatura, entre otras), el testimonio será pensado como una modalidad que opone, a la credibilidad de la experiencia, no el puro juego ficcional ni la reproducción factual de los hechos, sino su reconstrucción a partir de una mirada documental. Se impugna, de este modo, el carácter ficcional del relato para proponer una literatura en la que ese material adquiere distintas significaciones porque entabla nuevos campos de relaciones a través de un sujeto y sus diferentes modos de contar o poetizar.

Pensado en este sentido, el testimonio, más allá de las formas discursivas, propone en principio dos zonas de problemas: la primera referida al sujeto que da fe, testifica pero también formula alguna respuesta imaginaria ante el acontecimiento dado; en segundo lugar, la relación constitutiva de ese individuo con la verdad "por la cual una verdad es la suya sin dejar de ser verdad, y por otra parte, es verdad precisamente y sólo en cuanto es verdad de alguien, que la testimonia" (Vattimo 1986: 50). 


\section{La rosa blindada $y$ La muerte en Madrid: testimonios presenciales}

A propósito de la reedición de La rosa blindada en 1993, Juan Gelman comenta acerca de González Tuñón:

Advierto que hablo de Raúl en tiempo presente, pero no es en otro que de él se puede hablar. Ese hombre de memoria nítida, respuesta pronta y rica, modesto en el vestir, pobre siempre, de voz suave y cordial, ojos oscuros con el habitante de una chispa inagotable (de curiosidad, de cariño, de bondad, de admiración, de regocijo, de asombro no agotado) parece estar fingiendo que murió hace casi veinte años. No es verdad pero es poético como él dice en este libro (contratapa; cursivas nuestras).

Fingir la propia muerte para la verdad de la poesía, este es el gesto que Gelman rescata de Tuñón, la presentación de un sujeto poético que simula su muerte para estetizar la muerte de otros, para dar testimonio de una experiencia privada e impresentable, que pasa a ser una entidad puramente lingüística, es el que recupera la experiencia de lo real como vivencia, rescata lo impresentable, estetiza, da a conocer zonas veladas de lo real. No se trata de un sujeto ausente sino todo lo contrario, es un sujeto que deambula y transmigra presentando, a un tiempo, el mundo de los vivos y el de los muertos. Si los acontecimientos ocurrieron sin testigos, y "es imposible dar testimonio, tanto del interior -porque no se puede desde el interior de la muerte, no hay voz para la extinción de la voz- como desde el exterior" (Agamben 2010: 35), el sujeto poético asume esa tensión, esa postura imposible y testimonia precisamente desde ese no-lugar, desde una desubjetivación: está adentro y afuera a la vez, habita en ese umbral imaginario que separa el mundo arcaico de los muertos que desean volver para contar su verdad de la guerra ${ }^{2}$ y el universo de los vivos que están imposibilitados de testimoniar. "Sea como fuere, el origen mental de mis heterónimos está en mi tendencia orgánica y constante a la despersonalización y la simulación" dice Pessoa en sus Escritos intimos (cit. en Agamben 2010: 124) donde describe el fenómeno de la despersonalización heterónima. Tuñón como Pessoa habla de la experiencia poética como un proceso complejo que pone en juego al menos a tres sujetos $-\mathrm{o}$, mejor dicho, subjetivaciones-desubjetivaciones, porque no es posible hablar estrictamente de sujeto, en esta zona de indeterminación es imposible asignar la posición de sujeto, identificar al yo con el testigo-: el poeta que escribe y realiza el acto poético, que atestigua y para hacerlo tiene que despersonalizarse; el que no puede atestiguar porque está muerto; y el que adquiere una consciencia poética (el ethos de la poesía) que vuelve a subjetivarse luego de sobrevivir a ese necesario estado de no ser nadie para lograr una experiencia poética testimonial que evidencia que todo testimonio es "un proceso o un campo de fuerzas recorrido sin cesar por corrientes de subjetivación y de-subjetivación" (Agamben 2010: 127).

Tanto en los poemas de La rosa blindada (1935) -“testimonios líricos", según los define el mismo autor- como en el libro Demanda contra el olvido (1962), Raúl

También está la idea del mundo arcaico en la intervención de la magia: los muertos que no han tenido el ritual funerario regresan, amenazantes o espectrales, al mundo de los vivos para buscar justicia o venganza. 
González Tuñón configura un sujeto poético que profesa como verdad su propia existencia, y desde allí da testimonio sobre la realidad y sobre lo irreal de lo real. Este sujeto se identifica según el pathos existencialista porque recupera la subjetividad como verdad y tematiza la concepción de "lo auténtico" como proyecto individual y humano (Vattimo 1986: 50). Da testimonio de la muerte de otros desde su propia experiencia de la muerte. Este sujeto lírico y testigo se configura como sujeto "trascendente" porque traspasa, atraviesa los límites socialmente demarcados para la muerte y la representa de otro modo, ubicándose como "medium" entre la experiencia heroica del pasado mítico y la experiencia utópica del futuro revolucionario, entre el cuerpo despiezado y el alma que perdura. No se niega a sí mismo, sino que cede su realidad y es todos los muertos, todos los sujetos de una clase, es la voz de los individuos sin Estado o de los sujetos muertos por el Estado, es el canto de su barrio, de su pueblo y de todos los pueblos que intuyen su presencia y necesitan de su testimonio. En su voz de "juglar" y "prestidigitador" se conjugan todos los sujetos poéticos y los poetas que conforman la historia de la experiencia estética, desplegada en los intersticios de la historia literaria. Son las voces de una comunidad de autores aunados para la memoria poética; incluso el sujeto Raúl González Tuñón es un perfil más del sujeto imaginante (Catoriadis 1994) y habla de sus vivencias de infancia y de su oficio de escritor. Ni el canto, ni el poema pueden intervenir para salvar el imposible testimonio; al contrario, es el testimonio el que posibilita el canto y origina el poema: "Padres, abuelos, sí, vuestra ceniza / como lo fue la firme carne vuestra / es laboriosa, y en nuestra ceniza / próxima late la victoria cerca (1993: 55)."

La poética de Raúl González Tuñón presenta distintas formas de representación de la memoria y los múltiples "sitios de la mirada": una memoria sensitiva (la percepción de una experiencia garantiza el testimonio); una memoria poética (la estetización de esa experiencia se presenta como una versión contra-fáctica); y una memoria topográfica (que recupera los espacios de la experiencia pasada y futura).

A través de esta memoria anticipada Tuñón busca reconciliar en la poesía al sujeto con la experiencia que le ha sido expropiada (Agamben 2000). Este sujeto poético restituye o completa artísticamente lo que en el presente se ha fragmentado u oprimido, por eso sacrifica su existencia, su corporalidad para que emerjan las imágenes subsumidas en la tierra. Puede regresar al pasado histórico y recuperar la experiencia perdida: de este modo el sujeto Raúl González Tunón, escritor de izquierda, viaja nuevamente a España, a París y también a la Rusia del `30, dejando de ser un viajero tardío, el gran ausente en la Revolución, y capturando una experiencia original y auténtica. La poesía permite, como oposición a la "muerte en serie", la "muerte propia", "la muerte que cada uno lleva dentro de sí (...) la muerte que 'se tenía' y 'daba a cada uno una dignidad singular, un silencioso orgullo" (Agamben 2010: 75).

En La rosa blindada hay series de imágenes consteladas que retornan insistentemente en los poemas, formando la alegoría de la Revolución Eterna. No se trata de metáforas continuadas sino más bien de un conjunto de sentidos que en los poemas se re-significan y dan cuenta de la experiencia revolucionaria (también

En Tuñón, esta imagen romántica del poeta mediador entre los muertos, los humanos y la divinidad, del poeta como traductor del mundo, como ser sobrenatural, proviene de dos vertientes poéticas: por un lado la de Wordsworth, luego de Emerson y Whitman, por otro la de Baudelaire, Hölderlin y Verlaine. 
el nivel simbólico es testimonio indeleble del imaginario político: la rosa, el rojo, las banderas, los himnos). Estás imágenes no son estáticas, son nómades como el sujeto, circulan, mutan diseñando figuras. Una serie es la que toma el motivo del viento trashumante como fuerza que disemina por azar elementos en el espacio, corriente producida naturalmente que dispersa sentidos sin orden ni causalidad. El sujeto poético prosigue la expansión y la intensidad del viento por los distintos espacios reales e imaginarios; y el tiempo de la experiencia, a su vez, es un tiempo circular, el viento trae el "tiempo recurrente", tiempo espiralado, "en retroceso", "el tiempo de ayer en hoy", "...un tiempo que gira en torno al hombre sin alterar su esencia...". Este "viento blindado" se mueve en un tiempo épico y conlleva la alegoría del éxodo popular, la de los grupos humanos esclavizados que buscan un territorio para vivir en libertad: "de la caravana de los desposeídos, las largas filas de linyeras forzados" (Tuñón 1993: 46). A partir de aquí surge una nueva serie que está emparentada con la anterior, y en la cual Tuñón presenta la figura de la nave que atraviesa un mar en tempestad y arriba al puerto que es la salvación: imágenes provenientes de a la tradición poética griega y los romances españoles que son alegorías de la supervivencia del héroe frente a un contexto hostil.

Otra de las series está conformada por las imágenes de la metamorfosis, que dan cuenta de la transformación de los cuerpos y de las figuras que éstos arman en contacto con los minerales, y de la proliferación de los miembros en plantas o en ríos subterráneos. Ya no hay rastros del cuerpo humano ni de la expresión humana, sino huellas de subjetividad en el mundo natural. El sujeto poético realiza un doble recurso: en primer lugar, representa la muerte seca, el resquebrajamiento de los cuerpos, para después presentar la arborescencia de los cadáveres, el florecimiento de un sentido perdurable como en las leyendas folklóricas en las que un hombre anónimo deviene árbol o flor o agua y su nombre trasciende lo sucesivo del tiempo histórico, inscribiéndose en el relato mítico como emblema de heroicidad o testimonio de un suceso universal ${ }^{5}$.

La sangre es una imagen en movimiento, no es evidencia o prueba de la muerte sino el fluido que, mezclado con las sustancias inorgánicas de las minas en las que trabajaban los obreros fusilados, permite el crecimiento o el reinicio de la vida en la misma naturaleza. Los cuerpos no se desintegran sino que continúan siendo energía a partir de la fusión con el carbón, “...Donde el carbón se junta con la sangre...". Se restaura así el ciclo natural y de las cenizas retorna la experiencia destruida: "La sangre cayó a la tierra / de la cuenca de su pecho. / La tierra se fecundó / con la sangre del minero" (15).

El sujeto poético presenta las distintas figuraciones de los cuerpos en sus metamorfosis, prosigue el curso de los "riachuelos de sangre" y se detiene en los "coágulos de lágrimas". Confía en que, a través de su martirio ${ }^{6}$, dispone de una

4 Tomo esta idea del ensayo de Alejo Carpentier "Problemática del tiempo y el idioma en la moderna novela latinoamericana".

5 En su derrotero poético, Tuñón recurre a esta imagen de los muertos que ven nacer las lilas. En El rumbo de las islas perdidas (1968), los ojos de los muertos alcanzan a ver la temporalidad en suspenso, en el fluir de las imágenes fantasmales. Estas imágenes transitan subterráneas y fuera de la cronología y del curso unitario y lineal del relato que causalmente propone la historiografía de la guerra.

6 Como plantea Agamben, testigo en griego se dice martis, mártir. Los primeros padres de la Iglesia acuñaron a partir de ahí el término martirium para indicar la muerte de los cristianos perseguidos que de esa forma daban testimonio de su fe. Lo sucedido en los campos de concentración alemanes tiene muy poco que ver con el 
verdad, y que su vida tiene un valor de prueba, su existencia es testimonio de una verdad histórica; cree que -como el mártir cristiano- el sacrificio de su realidad es un modo de afirmar esa verdad. Propone así "una memoria de la especie": "...un sistema de representaciones que fija la conciencia (y el inconsciente) de los sujetos a una estructura de reconocimientos sociales, culturales, institucionales, y por supuesto ideológicos. Que lo ata a una cadena de continuidades en la que los sujetos pueden descansar, seguros de encontrar su lugar en el mundo..." (Grüner 2001: 17). Esta memoria es también una memoria de la intimidad y no pública. Los cuerpos exhibidos en la plaza o contra los muros de fusilamiento son monumentos, íconos de una memoria que se manifiesta por debajo de las tumbas en la transformación de los cuerpos, sobrevolándolas cuando logran trascendencia en el sujeto lírico.

Esta memoria poética, en tanto anticipa la repetición de la experiencia artística que se esconde en la realidad, tiene una función utópica, política de la literatura, se traslada sobre las ruinas, los baldíos, los basurales y los cementerios buscando en lo residual la repetición, la continuidad, el material para estetizar la experiencia. La representación de los cementerios proletarios como zonas del territorio poético, escenarios para la poesía, como espacios que escapan al control estatal, puede compararse con la estetización del suburbio que en su deambular urbano realiza el poeta y cronista Raúl González Tuñón.

El sujeto lírico en su andar descubre cementerios encubiertos, lugares donde yacen individuos sepultados sin sacramento, sin un ritual mortuorio, sin la ceremonia de la institución: muertes asociales, sujetos no velados y restos de cuerpos mezclados en la fosa común. Su mirada tiene la propiedad de testimoniar a través de las imágenes poéticas. Sólo la poesía puede hablar de lo irrepresentable (Agamben 2010). La escritura capta la muerte y presenta los cuerpos metonímicamente. Poetizar es un modo de restituir a los sujetos un territorio propio. Al asignarles un espacio imaginario, el sujeto poético legitima sus identidades desterradas, forzadamente desaparecidas, reúne los fragmentos de los distintos cuerpos para armar uno único: el ejército de los desposeídos:

En Santa Cruz, entre el mar y los montes

yo he visto el pequeño cementerio de los huelguistas fusilados.

Unos mal enterrados, en la fosa abierta por ellos,

asoman la punta del zapato con tierra y lagartijas.

Otros enterrados vivos quizá,

Una mano de hueso implorante picoteada por los cuervos.

Y no es extraño ver a lo largo del camino restos de otros,

curioso contenido de la intemperie.

martirio. Sobre esto hay unanimidad entre los que sobrevivieron a ellos: "Llamando mártires a las víctimas del nazismo, mistificamos su destino". Hay, sin embargo, dos puntos en que esas dos cosas parecen aproximarse. El primero se refiere al propio término griego, derivado de un verbo que significa "recordar". La doctrina del martirio nace, pues, para justificar el escándalo de una muerte insensata, de una carnicería que no podía parecer otra cosa que absurda. Frente al espectáculo de una muerte aparentemente sine causa. 
En La rosa blindada la memoria de la percepción poética presenta los sentidos del olfato, del tacto y oído tanto como el de la vista. La visibilidad del sujeto lírico atraviesa los cuerpos, pasa entre los órganos, circula entre las sustancias que conforman la tierra pero no puede leer los nombres inscriptos en las tumbas y su mirada conduce la visibilidad de aquellos que tienen la vista fija en una única zona de lo real, desviando el centro de la mirada y modificando la focalización del sentido: "No, no vengáis a ver la gloriosa tumba. / El musgo es lo más bello de la estatua [...] / Venid a ver mejor el paredón con sangre, / el ejemplar suburbio de la muerte" (53).

La memoria poética es también una memoria sensitiva, unificadora de experiencias particulares, es la memoria que trae los sonidos, las texturas, los olores del mundo del trabajo y la experiencia sensitiva y emocional de los trabajadores, las voces del mitín, junto a los sonidos de la muerte: “...de pizarra y piedra fresca [tacto] / nacen las musicales herrerías [sonido] / y los crudos ladrillos y los soles / -carros con panes, albañilería- / olor de maquinarias curtidoras, [olfato] / vastos colores de quincallerías, [vista]/ rumor de alfarerías y telares / y tahona y modista y lechería / y el rencor popular y tu recuerdo / y la revolución oh siempreviva" (55).

En La muerte en Madrid, este sujeto poético presencia y contempla los acontecimientos desde la trinchera. La Muerte llega a Madrid personificada, como en las alegorías de los romances medievales, en un recurso que Tunón retoma de García Lorca. El poeta, que en este caso (a diferencia, como veremos, del caso de Rusia) se corresponde con el viaje y la participación activa de Tuñón durante la Guerra Civil Española, es testigo de la llegada de la Muerte a la ciudad y enuncia a través de imágenes poéticas su encuentro con "El primer hombre muerto" en la guerra:
Allí nomás, al lado de mi mano, estaba el primer hombre muerto.
El primer hombre muerto que veo
en la guerra tremenda y desmedida.
Después de los lanzabombas, después de caminar entre raíces
bajo un sol recaído y con ausencias
y mariposas súbitas y locas de balas fugitivas,
vi al muerto de pronto cerca de la trinchera
y estaba solo y seco como un brote de la tierra
definitivamente incorporado
al lado de mi frente
extendido y exacto como todo cadáver.

Esta vez el poeta atestigua sobre la extrañeza cadavérica. La imagen del despojo mortal, como dice Blanchot,

escapa de las categorías comunes: hay frente a nosotros algo que ni es el viviente en persona, ni una realidad cualquiera, ni el que estaba vivo, ni otro, ni ninguna 
otra cosa. Lo que está allí, en la calma absoluta de lo que ha encontrado su lugar, aunque el muerto se apoye pesadamente como si fuese la única base que le queda. Justamente esta base falta, falta el lugar, el cadáver no está en su sitio. ¿Dónde está? La presencia cadavérica establece una relación entre aquí y ninguna parte (245).

El sujeto lírico no puede atribuir sentido a su visión del muerto y convoca a todos los que quieran ver ese cuerpo que es ahora documento de la historia de la muerte en Madrid.

\section{Himno de pólvora. Tiempo del héroe. Poesía de guerra (1943)}

Levanta el césped con tu rudo arado, Muerte, y ahonda el surco para sembrar...

Longfellow

El testimoniar significa ponerse en relación con la propia lengua en la situación de los que la han perdido, dice Agamben, instalarse en una lengua viva. Este es el gesto del poeta, que como testigo funda la lengua como lo que resta, lo que sobrevive en acto a la posibilidad -o la imposibilidad- de hablar. La lengua poética es la que se ubica siempre en posición de resto y de este modo puede dar testimonio. El sujeto lírico de Tuñón testimonia sobre lo no enunciable, incluso habla de su incapacidad de decir. El testigo poetiza desde el umbral que existe entre los muertos y los supervivientes, entre los hundidos y los salvados.

Sylvia Saítta, en el prólogo al libro Hacia la revolución. Viajeros argentinos de izquierda, plantea una idea iluminadora acerca de la experiencia revolucionaria en el siglo XX: "A partir de la Revolución Rusa de 1917, la noción misma de revolución se espacializa, porque desde entonces delimita un territorio y funda un escenario que, precisamente por eso supo convocar viajeros, cronistas, intelectuales y políticos de todo el mundo" (11). González Tuñón escribe Himno de pólvora mientras vive en Chile: en ese momento trabaja en el diario El siglo y vive la guerra en Europa a partir de las noticias que le llegan de sus compañeros y de su lectura periodística. Esta vez no está en el campo de batalla y tampoco viajó como sí lo hicieron sus amigos o camaradas de izquierda a los países en los que la experiencia revolucionaria se convirtió en un modelo existente de sociedad: " $\mathrm{A} \mathrm{Ah}$, los guerrilleros! Es fácil escribir esta palabra. Es fácil imaginar la hazaña desde aquí, mirando por esta ventana, escribiendo en esta Remington, portable, fumando y charlando con los compañeros. De pronto, no sabemos qué decir" (63).

En este libro el poeta González Tuñón es un testigo imaginario, es un cronista que da cuenta de hechos vividos por otros, pero los presenta como si fueran vivencias propias. Escribe en 1943 acerca de lugares, personas y acontecimientos que no presenció, a partir de imágenes que recrea de las versiones leídas en la prensa acerca de la Revolución, de la Unión Soviética, de Lenin, de Stalin, de la Segunda guerra y de las escenas que terminaron siento hitos decisivos para la historia, como el encuentro entre Lenin y Stalin o el episodio de los asaltantes del Palacio de Invierno en 1905. Incluso remite a fragmentos de diálogos, utilizando el 
estilo directo y citando imaginariamente las voces de los protagonistas de esas escenas históricas:

\section{LA CASA DE TCHAIKOVSKI}

Yo no estuve en Rusia, desgraciadamente. No conozco, por eso, Moscú. Tampoco desde luego conozco Klin. Es decir: nunca visité la casa-museo de Tchaikovski. [...] Diréis entonces: “¿Cómo es que este hombre se atreve a hablarnos de la casa de Tchaicovski, sin haberla conocido?” ¡Ah! He aquí el secreto. Yo no estuve, pero estuve. Un poeta está en todas partes. Debe estar. Yo estaba precisamente allí, en Klin, en la casa de Tchaikovski, cuando ocurrió aquello (123).

Un sujeto imaginante recupera la consciencia histórica de los hechos en el momento en el que los mismos protagonistas no podían tenerla todavía. Recrea las imágenes que surgen de la lectura de noticias periodísticas o crónicas de guerra o material de la biblioteca del partido. El tiempo transcurrido le permite al sujeto poético volver al tiempo de gesta y también puede en el presente de la experiencia primera realizar comentarios sobre la importancia de lo que está aconteciendo, ubicándose a la vez en una temporalidad histórica.

A partir de Lenin y Stalin escribe las epopeyas sobre el origen del espíritu revolucionario de los héroes: los imagina en la infancia, en el inicio de sus vidas políticas y los ve también en el momento de sus muertes, en sus tumbas, visitados por sus seguidores y fieles camaradas. También el sujeto poético comparte la escena:

LENIN. Bajo los mármoles sombríos del mausoleo yace el hombre en la urna de vidrio. Los soldados desfilan cerca de su muerte tendida [...] ¿Pero, es que él está allí yacente y muerto? ¿Con él murió tanto fervor, tanto instinto, tanta sabiduría, tanto coraje, tanta bondad? No, porque allí donde miremos allí está su obra (69).

Las biografías poéticas de Lenin y Stalin son estampas de hombres con virtudes sobrenaturales. Son alabados y venerados como dioses o ángeles. Los retratos poéticos que escribe son imágenes líricas que vuelven a las figuras legendarias, místicas, incluso espirituales y auráticas dentro de un paisaje que se vuelve pintura para el lector. Tuñón presenta imágenes que tienen una identidad colectiva que todos vemos aunque sea el poeta quien las escriba: el sujeto poético se despersonaliza en la imagen y se pierde en un "nosotros vemos", la experiencia es una visión compartida, unida en un pacto mágico en la representación de lo real, tal y como sucede en los milagros. El sujeto lírico cuenta la experiencia milagrosa de la revolución que no necesita comprobación empírica sino poética, la verdad está en la poesía, única lengua capaz de dar testimonio de la intervención divina en la realidad: la Revolución es una cuestión de fe.

Tuñón tiene una versión auténtica aunque mire a través de la visión de otros, porque esos otros que estuvieron presentes y vieron o ven lo que él no pudo ni puede todavía, son como él mismo y comparten la mirada. Existe entonces una experiencia compartida y única de la Revolución, la experiencia es privada y a un 
tiempo colectiva y social. Por eso Todos los hombres del mundo son hermanos, el libro que escribe como resultado de su primer viaje a Rusia, en 1954, es la confirmación de lo que imaginó literariamente una década atrás, es la concreción de la utopía del partido, la admiración del proyecto político materializado. La visión empírica de 1954 coincide con la imaginaria de 1943.

En Himno de pólvora, el testimonio poético es un canto guerrero en el que González Tuñón comparte la enunciación con los muertos: "Los muertos y nosotros decimos que no, que no todo volverá a ser como ha sido", "ya no es posible vivir sino viviendo y ya no es posible morir, no, no es posible, porque la Victoria es el Hombre y su Eternidad" (77). Las tres partes del libro -"Tiempo del héroe", "Los nuevos motivos del lobo" y "Poemas de la guerra"- presentan una lírica testimonial, cantares de gesta sobre los héroes inmortales, relatos poéticos acerca de la violencia del nazismo, descripciones de lugares utópicos en los que se vive y habita la revolución, epopeyas de héroes patrióticos, crónicas de asesinatos políticos, elegías a los muertos en batalla. Las figuraciones retóricas propias del imaginario sobre la muerte se acercan en este libro a la composición del himno. Si bien se trata de una forma poética pensada originariamente para ser cantada en coro en honor a un dios, del que se recuerdan advocaciones, favores o prodigios, Tuñón retoma el himno en su doble carácter religioso y literario, recurriendo a formas poéticas como la oda, la elegía o las canciones corales, y dirigiendo la voz del poeta en una doble dirección: por un lado, una enunciación lírica emparentada con el tono litúrgico de las ceremonias eclesiásticas, con la conmemoración y el lamento; por otro, una subjetividad poética que une voces en torno a sentimientos patrióticos, bélicos, civiles y políticos. La metáfora "himno de pólvora", como "la luna con gatillo" o "la rosa blindada", es la modalidad retórica que evidencia la función de la poesía como arma o instrumento de combate y la concepción del lugar desde donde el poeta puede, intervenir en lo social y dar testimonio sobre la guerra y sobre la muerte.

Los imaginarios de lo subterráneo, de la profundidad de la tierra y de lo que está abajo invisible y luego se visibiliza están presentes en la poética de Tunón desde sus primeros libros, pero en Himno de pólvora es central la idea de la resurrección de los muertos anónimos que vienen de lo oculto de lo social. Sin embargo, esta idea es considerada en un sentido contrario al "horror oculto" del cuento fantástico de Lovecraft. Para Tuñón lo subterráneo no es el infierno individual del sujeto, ámbito de lo inquietante, siniestro o temible, sino que tiene relación con el imaginario de lo social, la profundidad y lo invisible en tres sentidos: como hipogeo ligado al imaginario de la cavidad subterránea donde se conservan los cadáveres de los rechazados o abandonados por el Estado; como inframundo, lugar imaginario habitado por los espíritus de los muertos; y como profundidad radical, que no es el imaginario del vacío sino de la invisibilidad, una oscuridad o un exceso de brillo. Los tres aspectos refieren a lo oculto de lo social que la poesía restituye como representación posible (Cabrera 2007: 101).

En Edgar Lee Masters el imaginario de la cavidad subterránea está asociado a las tumbas privadas con nombres propios en las que fueron depositados los cadáveres de los que ya no pueden transformarse y renacer. Los muertos están inscriptos en un cementerio que instituye la muerte en una tradición privada genealógica y en una memoria resguarda por el Estado. Los muertos del Spoon 
River sólo pueden ser apariciones fantasmales que denuncian los fracasos sociales e individuales y sus voces son pruebas de que no hubo transformación ni resurrección de los cuerpos porque nunca hubo un verdadero cuerpo social desde el cual poder trascender la muerte o vivir en otros como continuidad. Tuñón utilizará posteriormente el recurso de la prosopopeya de Edgar Lee Masters en Demanda contra el olvido y es un modo particular del testimonio; en Himno de pólvora, los cadáveres reviven cuando el sujeto poético profiere una invocación sagrada. Como dice el mismo autor, los cadáveres son acontecimientos, hombres que sobreviven en el proyecto comunista que los convoca a la inmortalidad, a la eternidad cíclica de pervivir en otros revolucionarios:

\section{TRES CABEZAS EN EL PATIO DE LA SANTE}

El verdugo recogió las cabezas, una por una -habían rodado por el patio húmedo de la madrugada, y las colocó en la canasta.

Luego sus ayudantes recogieron los cuerpos sin cabeza y los metieron también en la canasta. Primero fue un hilo de sangre, después un charco, después un arroyo de sangre (mañana será un río, y desbordará y arrasará con todo...)

[...] En el cementerio ya estaba abierta la fosa, en el gran terreno común. El funebrero y su ayudante vaciaron la canasta... y se marcharon. No sabían que acababan de darle a la tierra un sentido profundo, un contenido maravilloso. No sabían que enriquecían la tierra, sus jugos vegetales, sus secretos carbones. ¡No sabían que, con su gesto, al volcar la canasta, arrojaban simiente a la tierra! (111)

La función política del escritor, del poeta y de la poesía es develar una verdad ideológica a través de la puesta en escena de la muerte. El sujeto lírico en el escenario del crimen presenta las imágenes del delito, de los cuerpos acribillados, despedazados, de los cadáveres que pasan a ser metáforas, símbolos o emblemas de la Revolución, y la crónica da lugar entonces al espacio espectacular, a la teatralidad de las imágenes sensoriales, a la atmósfera trágica que provoca empatía en el espectador, luego la catarsis y posteriormente una conmoción reveladora de verdades sociales. La representación del momento de la catástasis y la catástrofe de la tragedia griega es el recurso que permite lograr un estado de consciencia, y escribir es, entonces, una puesta en acto de las ideas políticas, una modalidad para intervenir en lo social a través de un discurso poético originado en la oralidad de la plaza pública; de este modo, la retoricidad de los poemas tiene más que ver con la dispositio argumentativa que con los recursos poéticos de la versificación. Así Tuñón encuentra en la lírica la posibilidad de tramar poéticamente discursos sociales con intención persuasiva, y en la subversión de ese tramado discursivo aparece la verdad de la poesía. El discurso del orador político, del militante, del poeta, se cruza con los de las figuras bíblicas de los peregrinos, de los profetas, de los apóstoles, los caminantes que en su recorrido espiritual hallaron signos o evidencias de la existencia de Dios y van anunciándolas a quien quiera oírlos. El sujeto viajero de Tunón en Himno de pólvora no es Juancito Caminador, ni un sujeto poético entre pícaro, delincuente y bohemio que da cuenta de la vida en los suburbios de la ciudad; es un sujeto revelador de la palabra divina que augura tiempos de gloria luego del padecimiento y del sacrificio por la causa. El discurso político, partidario en su solemnidad, se entrecruza así con la liturgia del 
comunismo, la celebración de la palabra religiosa, el himno que se canta en homenaje al creador del mundo. Y busca hablar acerca de la existencia de una justicia que va más allá de las instituciones, la justicia social, anticipando el regreso de la edad dorada. De este modo, la muerte de los inocentes y los sacrificios se resignifica en un renacimiento político que adopta vestiduras religiosas. Los sentidos de la muerte surgen cuando el sujeto lírico profiere un discurso poético y propicia la ceremonia sagrada: por entre las ruinas, el ejército angelado de los trabajadores reconstruye la ciudad, o hace su aparición el ángel de las barricadas como mensajero divino del espíritu revolucionario en momentos de injusticia social, o cuando el pueblo es masacrado.

El sujeto poético canta Gloria luego de la descripción de una obra ideada de acuerdo al plan primero de Lenin o de Stalin, y también como celebración de la vida en la muerte. El canto o el recitado litúrgico de la Gloria responde, en las ceremonias cristianas, a la instancia celebratoria en la que se realiza la alabanza al final de la Creación de Dios. Gloria es el esplendor de la belleza y perfección de lo creado, es el himno que expresa la adoración, el amor extasiado ante la belleza del plan divino. El sujeto poético de Tuñón expresa ese deslumbramiento por la creación del proyecto comunista en un tono exaltado que pretende motivar y buscar adhesión. Desea trasmitir la fascinación por la obra soviética que, al igual que la gloria de Dios, es el principio y el fin de toda la creación. Por eso cree tener la responsabilidad de comunicar con tono exhortativo este mensaje político y sagrado a quienes lo desconocen. En este misterio teológico o secreto inenarrable que sólo puede admirarse o alabarse en el canto de gloria, Lenin es el principio, la fuente y el origen de la vida revolucionaria, no engendrado, no creado, es el principio en cuanto que es aquel de quien otros proceden; sólo Él puede sin motivo o causa empezar a crear para siempre. Stalin, en cambio, es presentado como un visionario histórico que supo ver que el comunismo nunca fallará si se alcanza fidelidad a la causa original, que es pura espontaneidad, creatividad inagotable. El proyecto stalinista es generador, originante, fecundo incluso después de la destrucción, de las ruinas, del exterminio nazi. El sujeto lírico en su himno de gloria recupera esos sentidos que habitan en todos los comunistas, describe cómo la belleza de las imágenes de Stalingrado es la expresión del esplendor comunista, de la perfección política que suscita admiración y adoración. Así, la gloria a los muertos consiste en que se realice esta manifestación y esta comunicación de las bondades de morir por una causa para la que el nuevo mundo ha sido creado: "iGloria eterna a los que cayeron en la lucha por la liberación de nuestra patria!" (57). La poesía, entonces, es testimonio de la glorificación de los ideólogos de la revolución y de los muertos.

\section{Demanda contra el olvido: la ausencia presente}

En el poema que inaugura el libro Demanda contra el olvido, "Cantata para nuestros muertos", se diseña este sujeto que desde un dispositivo de enunciación múltiple presenta los discursos testimoniales de las víctimas de las policías "bravas", de la sección Especial, de los "aliancistas" y otros mercenarios, a veces aleccionados por los agentes nazis y del FBI: 
- Somos los torturados y los asesinados: un gran fervor yacente.

(Hablan desde la muerte, la otra faz de la vida)

Los que hemos sufrido cárcel, destierro y hambre, el relámpago gris del látigo en la espalda y la bala cobarde.

Porque hay una verdad en la imagen más que en la palabra, este sujeto lírico se ubica como garante de la verdad de la Imagen. Si en la Modernidad el sujeto que oficiaba como autoridad ha muerto y el vacío ha sido ocupado por "...la Religión de la Mercancía que satura todo el espacio de la mirada..." (Grüner 2001: 53), González Tuñón propone un sujeto que se define como pura mirada que disuelve su materialidad y se somete a las demandas de los otros sujetos (pobres, guerrilleros, combatientes, campesinos, desocupados, militantes, niños, otros) que lo intuyen y lo reclaman como la voz legítima para la representación y restitución de las imágenes del corpus social borrado. El sujeto poético hace posible el milagro de la resurrección de la experiencia y de los héroes anónimos.

La memoria del canto a los héroes que el sujeto poético proyecta establece un vínculo entre la comunidad de los vivos y la de los muertos en el dominio público, pero dentro de una tradición poética y no en el marco de una tradición cultural o nacional. A través de los cantos de gesta, de glorificación y alabanza, los personajes y poetas desaparecidos adquieren existencia social, valor de continuidad, gracias al sujeto poético que unifica certezas privadas.

A su vez, tanto cuando recupera las figuras de los "hermanos poetas" desaparecidos como cuando traduce la voz de los muertos olvidados por el Estado, este sujeto ficcional resguarda la memoria poética y una historia legendaria, fabulosa de la experiencia estética de la muerte. Se trata de una memoria anticipada liberadora de vidas inconclusas, de las historias que no pudieron ser por quedar atrapadas en el cuerpo muerto: el sujeto revela sueños de la vigilia y encandilado relata las imágenes de la Revolución y los secretos de esas imágenes:

Canté con los huelguistas de todas las latitudes

en las ardientes fábricas y en los puertos sombríos.

[...]

Inventé el acordeón y la imaginería,

los himnos populares que incitan y arrebatan

como ese del insigne zapatero Pottier

y la Opera de Dos Centavos con Bert Brecht.

No busco la evasión en las torres ebúrneas

ni proclamo la copia servil o el sonsonete

de los naturalistas trasnochados

y el beato marxista que esconde al crudo cuáquero.

(1963: 51) 
"La ausencia presente", "Sólo unos cuantos nombres de la larga memoria", "Apasionado elogio" y "Final y esperanza" se titulan las siguientes secciones del libro; en ellas el sujeto lírico recurre a las formas poéticas tradicionales para la representación de la muerte: la elegía y el epitafio. Retoma la elegía porque es el género que pone en tensión la zona de la poesía cívica, pública, y el espacio de la subjetividad lírica como exaltación de la figura del poeta melancólico que elige el cementerio como escenario para la poesía.

En los epitafios, el sujeto poético retoma el lugar de enunciación del poeta norteamericano Edgar Lee Masters en su libro The Spoon River Anthology. El sujeto poético cede la enunciación, abre un espacio en el poema para que otros hagan su alegato, sus acusaciones póstumas, sus confesiones, los sujetos que dicen "yo" realizan sus autobiografías condensadas, se autorretratan, tienen nombre y cumplieron un rol determinado en la sociedad. El sujeto imaginario traduce experiencias ajenas y, de este modo, establece un juego de correspondencias entre el sujeto-poeta, los sujetos- personajes y su traducción poética. Esta filiación de González Tuñón con el Spoon River puede interpretarse como la búsqueda de la utopía pre-moderna, en la cual los lazos intersubjetivos son los de una comunidad familiar y contrastan con las fracturas y contradicciones que vislumbran la distopía social en la Modernidad. El sujeto lírico vuelve a una Edad de Oro pre-capitalista buscando el espacio por donde circula el deseo utópico. Tuñón escribe un epitafio para Edgar Lee Masters en el que inscribe sus coincidencias poéticas, y al mismo tiempo testimonia acerca de una experiencia soñada que quedó enterrada gracias a un proyecto que oprimió la libertad del sujeto que "como una corista de Spoon River veló su sueño sin mañana.": "Escribió un epitafio de amor para la tumba / escondida y agreste de la novia de Lincoln. / El suyo fue un lirismo profundo y generoso / como el largo horizonte, allá en Kansas. / Seres humanos, cosas, nutrieron sus poemas. / La libertad -como una corista de Spoon River- veló su sueño sin mañana" (37).

El sujeto testimonial de Raúl González Tuñón configura un repertorio de imágenes para la representación de la muerte: la muerte de un ser querido, las muertes anónimas, las muertes célebres, las muertes forzadas. "Para que el recuerdo, sustituto de la vida, fuese eterno y que por lo menos la cosa que decía la muerte fuese ella misma inmortal" (Barthes 1989: 162), este sujeto poético recupera esta experiencia a partir de una versión privada, imaginaria y estética.

En González Tuñón, tumbas escondidas y agrestes que ocultan nombres, piedras humedecidas por el moho, flores que nacen de la cadaverina donde el mármol se pudre, el musgo que embellece la estatua, son imágenes que muestran cómo la naturaleza y los muertos que son parte de ella invaden, cubren, corroen la representación institucionalizada de la muerte: los nombres no han pasado por el ritual funerario y la sepultura prosigue una genealogía familiar no oficial.

La memoria opera metonímicamente, como alegoría. La mirada del poeta certifica la verdad de esta experiencia de la muerte. Recupera restos de cuerpos sepultados sin ceremonia; revela el momento de la resurrección de los muertos. Los cuerpos resucitan en Tuñón a través de las imágenes retratadas.

El sujeto lírico inscribe una voz que, conforme a los recursos propios del epitafio y la elegía, permite la enunciación de los ausentes desde una mirada que insiste no en rememorar ni restituir el pasado sino en testimoniar lo que ha sido. Da 
cuenta literariamente de una subjetividad imaginaria que corresponde a una clase determinada: el proletariado internacional.

\section{Conclusión}

En la tensión entre realidad y ficción, entre los hechos efectivamente ocurridos y su construcción narrativa, la poética de Tuñón testimonia, con matices y modalidades propias en cada uno de los libros analizados, la muerte en forma singularizada, y el sujeto poético es el pasaje en que todas las subjetividades negadas u olvidadas encuentran su lugar en la memoria; de este modo reencuentran sus voces y sus imágenes de la muerte, repasan sus vidas pasadas y futuras, e inscriben en la memoria individual la memoria colectiva. También cuenta su historia el sujeto lírico: "YO era un muerto y SOY todos los muertos. / Los que morimos, los que No morimos. / En los aniversarios del Partido / yo sé que el primer brindis será para nosotros. / Algo así como un himno formidable. / El alto Réquiem que vendrá grave y puro- / a poner rosas rojas y cantos como lámparas / en el hondo, en el largo país de nuestro sueño" (1963: 15). La huella que su poesía transcribe a partir de lo intestimoniado no es su palabra, es la palabra de los que perdieron la posibilidad de expresión. En el umbral de la experiencia, el sujeto lírico instaura un espacio poético que propicia el testimonio: "no era luz, pero estaba para dar testimonio de la luz" (Agamben 2010: 40).

Raúl González Tuñón escribe una poesía que puede dar testimonio poético de experiencias imaginadas que no dejan de ser ciertas y verdaderas. La impensable experiencia de la muerte se vuelve posible en el testimonio de un sujeto que de alguna manera desdibuja sus límites y confía en el poder de visibilidad de la literatura.

\section{Referencias bibliográficas}

Agamben, Giorgio. Infancia e historia. Buenos Aires: Adriana Hidalgo Editora, 2000.

- Lo que queda de Auschwitz. El archivo y el testigo. Homo sacer III. Valencia: Editorial Pre-textos, 2010.

Barthes, Roland. La cámara lúcida. Nota sobre la fotografía. Buenos Aires: Paidós, 1989.

Blanchot, Maurice. El espacio literario. Madrid: Paidós, 1992.

Cabrera, Daniel, "Lo imaginario o la centralidad subterránea", Revista Anthopos 215 (2007), pp. 92-103.

Cornelius Castoriadis, "Tiempo e imaginación” (1994). http://www.omegalfa.es/downloadfile.php?file=libros/tiempo-e-imaginacion.pdf febrero 2014).

González Tuñón, Raúl. Himno de pólvora. Santiago de Chile: Ed. Diap, 1943.

-Demanda contra en olvido. Buenos Aires: Horizonte, 1963.

— La rosa blindada. Buenos Aires: Libros de Tierra Firme, 1993 [1936].

- La Muerte en Madrid. Las puertas del fuego. Ocho documentos de hoy. Rosario: Beatriz Viterbo, 2011.

-El rumbo de las islas perdidas. Buenos Aires: Descierto, 2012.

Grüner, Eduardo. El sitio de la mirada. Buenos Aires: Editorial Norma, 2001. 
Saítta, Sylvia. Hacia la revolución, viajeros argentinos de izquierda. México: Fondo de Cultura Económica, 2007.

Vattimo, Gianni. Las aventuras de la diferencia. Pensar después de Nietzsche y Heidegger. Barcelona: Península, 1986. 